\title{
Gambaran Konsep Diri Anak Asuh di Panti Sosial PSAA 3 Ceger Jakarta Timur
}

\author{
Ellies Sukmawati
}

\section{Abstrak}

One of the challenges for social institutions to prepare foster children ready for their social life is in the process of formation and development of self-concept in children fosterage because these children do not have parents/family. This self-assessment concept picture using a qualitative approach to explore the concept of self-perception in children orphanage which is a cross-nursing, or children who have never known and the affection of his parents. llustration of this concept in terms of three factors: knowledge, judgment and hope that they perceived as a characteristic of the concept itself, and to know the description of these three things unearthed by 9 aspect ability to be critical, self identity, self-image, behavior, physical, moral self, social self, respect self, the ego of individuals in the family. The results of this study can be used as an instrument to create a model of care Alternatives which uses colleague system that gives a positive value in the development of self-concept of children in the orphanage, because they do not have a figure that is nurturing or loving as a parent, so that a sense of the need they can get from the friendship are mutually supportive and mutually reinforcing them.

Keywords: Children orphanage which is a cross-nursing (anak lintas panti), positive self-concept, negative self-concept.

\section{Pendahuluan}

Untuk menghasilkan sumber daya manusia (SDM) yang berkualitas dibutuhkan peranan orang tua dalam keluarga untuk mengasuh anak-anaknya secara baik dan mampu memenuhi kebutuhan anak-anaknya mulai dari bidang ekonomi, sosial, pendidikan, psikologi, kesehatan sampai dengan spiritual. Namun tidak semua anak-anak dapat menikmati kehidupan awal dan tumbuh kembangnya bersama orang tua, hal ini bisa dikarenakan karena anak tersebut terlantar diakibatkan oleh kurangnya tanggung jawab orang tua sebagaimana yang diberitakan di media tentang maraknya pembuangan bayi. Fenomena pembuangan anak sepertinya sudah merupakan hal yang sudah banyak terjadi di Indonesia, sehingga pengasuhan anak-anak terlantar tersebut selanjutnya diserahkan kepada panti sosial.

Walaupun pada dasarnya lembaga panti sosial bagi anak-anak asuh yang tinggal didalamnya adalah sebuah rumah dan keluarga, namun tetap saja keluarga yang terbentuk di panti sosial berbeda jika dibandingkan dengan keluarga sesungguhnya dengan orang tua yang lengkap, karena pengasuhan dan pemenuhan hak-hak sosial yang akan mereka terima juga akan berbeda, terlebih lagi menurut Sanusi (2013) keluarga merupakan lingkungan terbaik bagi anak untuk tumbuh dan berkembang, karena lingkungan keluarga akan memberikan pendidikan dan pengasuhan yang maksimal bagi anak-anak mereka yang nantinya juga akan mempersiapkan anak-anak mereka untuk menghadapi kehidupan sosial yang lebih luas.

Salah satu tantangan bagi panti sosial untuk mempersiapkan anak-anak asuhnya siap menghadapi kehidupan sosialnya adalah dalam proses pembentukan dan pengembangan konsep diri pada anak-anak yang diasuhnya karena anak-anak tersebut tidak memiliki orangtua/keluarga, padahal peran lingkungan terdekat yaitu orang tua merupakan tokoh sentral dalam pembentukan konsep diri seorang individu, kemudian teman dan selanjutnya masyarakat, karena dari mereka akan diper- 
oleh stimulasi berupa pengalaman-pengalaman baik yang bersifat reinforcement positif dan negatif maupun punishment yang kemudian dipersepsikan atau diterjemahkan oleh individu tersebut untuk menjadi bahan referensi baginya dalam menghadapi permasalahan kehidupannya ke depan

Berdasarkan penjelasan di atas terlihat bahwa menjadikan seseorang berdaya dan tangguh bukanlah permasalahan yang mudah, terlebih lagi membentuk konsep diri pada anak-anak di panti sosial karena ketiadaan orang tua yang seyogyanya berfungsi untuk melindungi, menyayangi, memotivasi dan memberikan contoh tidak mereka dapatkan. Dari keterangan di atas masalah mengenai gambaran tentang konsep diri pada anak-anak di panti sosial merupakan suatu topik yang menarik untuk diteliti, karena dari topik tersebut akan dipelajari secara seksama berbagai konsep diri yang dimiliki oleh anak-anak yang diasuh di panti sosial, karena ada suatu stigma yang melekat pada diri anak panti bahwa mereka adalah anak-anak yang nakal, suka berkelahi, sulit untuk diatur serta prestasi akademik yang rendah, sehingga pandangan dan penilaian dari masyarakat dan orang-orang sekeliling sangat memengaruhi konsep diri mereka. Studi akan semakin menarik terutama untuk melihat gambaran konsep diri khususnya pada anak diri anak panti dimana mereka sejak bayi atau balita sudah terputus hubungannya dengan orang tua dan keluarga, sehingga proses pembentukan dan perkembangan diri hanya di lingkungan panti dan masyarakat lainnya.

Berdasarkan uraian di atas, meneliti gambaran konsep diri anak di panti sosial adalah suatu kegiatan yang penting untuk dilakukan, hal ini didasarkan pada pemikiran bahwa pengasuhan di panti sosial tidak hanya terfokus pada terpenuhinya pendidikan formal, makan dan tempat tinggal saja, melainkan pembentukan konsep diri yang positif merupakan elemen yang tidak kalah pentingnya untuk dimiliki oleh seorang individu yang akan menjadi modal atau aset untuk kesuksesan hidupnya, karena tidak selamanya mereka menjadi anak tanggungan Negara. Suatu saat mereka harus mandiri berjuang untuk kesejahteraannya, sehingga walaupun mereka adalah anak yang dibesarkan di panti sosial namun mereka adalah aset bangsa sekaligus memiliki kesempatan yang sama untuk mampu berperan aktif dalam pembangunan ekonomi. Pemahaman KonsepPada artikel jurnal ini akan dipaparkan mengenai pengertian dari panti asuhan. Menurut Suyuti:

... panti adalah suatu lembaga atau satuan kerja yang merupakan prasarana dan sarana yang memberikan layanan sosial, dan “asuhan'yang mempunyai arti berbagai upaya yang diberikan kepada anak yang mengalami penelantaran, yang bersifat sementara sebagai pengganti orang tua atau keluarga agar dapat tumbuh dan berkembang dengan wajar baik secara rohani, jasmani, maupun sosial (Arif Gosita dalam Suyuti, 2010:37).

Panti asuhan menurut Kementerian Sosial RI merupakan lembaga usaha kesejahteraan sosial yang mempunyai tanggung jawab untuk memberikan pelayanan kesejahteraan sosial kepada anak terlantar, memberikan pelayanan pengganti fisik, mental dan sosial pada anak asuh, sehingga memperoleh kesempatan yang luas, tepat dan memadai begi perkembangan kepribadiannya sesuai dengan yang diharapkan sebagai bagian dari generasi penerus cita-cita bangsa dan sebagai insan yang akan turut serta aktif di dalam bidang pembangunan nasional (Suyuti, 2010:37).

Dalam sebuah panti asuhan terdapat anak asuh yang tergolong dari yatim, piatu, anak-anak terlantar dan mereka yang tidak mampu dan juga tidak memiliki rumah untuk tempat tinggal menetap dengan layak dalam kehidupannya. Anak-anak tersebut tidak hanya membutuhkan materi untuk kelangsungan hidup dan biaya pendidikan mereka. Anak yatim (maupun anak piatu, yatim piatu, 
ataupun anak terlantar) juga memerlukan kasih sayang, perhatian, dan cinta dari orang-orang yang peduli pada mereka. Di tengah kehidupan begitu berat yang mereka jalani, sudah bisa dipastikan hal itu akan menyebabkan mereka memerlukan perhatian dan kasih sayang yang lebih (Nur, 2009:87).

Dari hal tersebut maka, keluarga sangatlah diperlukan dan didambakan dalam hati para anak didik di panti asuhan, yang dapat memberikan kasih sayang, perhatian dan cinta dari keluarga baru yang mereka peroleh di panti asuhan, yaitu keluarga merupakan suatu kesatuan sosial yang diikat oleh adanya saling berhubungan atau interaksi dan saling mempengaruhi antara satu dengan yang lainnya, walaupun diantara mereka tidak terdapat hubungan darah (Sochib, 1998: 17).

Penelitian ini memfokuskan pada gambaran konsep diri yang dimiliki oleh anak panti asuhan, khususnya pada anak panti asuhan yang sedari bayi telah tinggal di panti asuhan atau yang sama sekali tidak mengenal kedua orang tuanya. Brooks dalam Rahmat (2001:99) menjelaskan konsep diri sebagai pandangan atau persepsi individu terhadap dirinya baik bersifat fisik, sosial maupun psikologis dimana pandangan ini diperoleh dari pengalamannya berinteraksi dengan orang lain yang memiliki arti penting dalam hidupnya, lebih rinci juga disebutkan aspek fisik terdiri atas penilaian diri individu terhadap segala sesuatu yang dimilikinya seperti tubuh, pakaian dan semua benda yang dimilikinya, aspek sosial meliputi peranan individu di lingkungan sosialnya serta penilaian dirinya akan peran tersebut.Sedangkan aspek psikologi mencakup pikiran, perasaan dan sikap yang dimiliki individu terhadap dirinya sendiri.

Terdapat 2 jenis konsep diri yaitu konsep diri positif yang menandakan kepribadian memadai dan konsep diri negatif yang merepsentasikan kepribadian yang tidak memadai. Ciri-ciri seorang individu yang memiliki konsep diri yang positif, yang dituliskan oleh Brooks dan Emmert dan dikutip oleh Rakhmad (2003:105) terdiri dari yakin akan kemampuan dalam menghadapi masalah, merasa setara dengan orang lain, menerima pujian tanpa rasa malu, menyadari bahwa setiap orang mempunyai berbagai perasaan, keinginan dan prilaku yang tidak seluruhnya disetujui oleh masyarakat, mampu memperbaiki dirinya karena sanggup mengungkapkan aspek-aspek kepribadian yang tidak disenanginya dan berusaha mengubahnya. Sedangkan konsep diri negatif menurut Erikson dalam Calhoun dan Acocella (1995:72) terdapat 2 ciri pribadi seseorang, yaitu: memiliki pandangan seseorang yang tidak teratur, tidak memiliki perasaan yang stabil dan utuh terhadap dirinya. Ciri konsep diri negatif yang kedua ditandai oleh pandangan seseorang dengan konsep diri yang stabil cenderung terlalu teratur atau dapat dikatakan terlalu kaku.

Lebih lanjut Mlinar and friends (2009:4) menuliskan 10 instrumen untuk menggambarkan konsep diri pada responden dalam penelitiannya, yaitu

1. Self-criticism (kritis diri): people who are highly critical of themselves are supposed to be defensive and prone to creating a favourable impression on other people; selfcriticism describes characteristics acknowledged as fairly non-desirable by the majority of people (individu yang sangat kritis terhadap diri mereka akan sangat defensif dan cenderung menciptakan kesan yang baik kepada orang lain. Self criticisim ini merupakan penggambaran akan karakteritik yang tidak menginginkan penolakan dari orang lain)

2. Identity (identitas): how individuals perceive themselves (who am I?) bagaimana seorang individu memandang diri mereka sendiri atau mampu bertanya siapakah saya?

3. Self-image (citra diri): how individuals feel about themselves (bagaimana perasaan individu tentang diri mereka sendiri) 
4. Behaviour (prilaku): how individuals perceive their own behaviour (bagaimana individu memandang prilaku mereka sendiri)

5. Physical self (fisik): encompasses how individuals perceive their own health, body and physical appearance (meliputi bagaimana individu memandang kesehatan mereka sendiri, termasuk di dalamnya tubuh dan penampilan fisik)

6. Moral self (moral diri): how individuals perceive their moral worth (bagaimana individu memandang nilai moral mereka

7. Personal self (diri pribadi): measures how individuals assess themselves as a human being (terkait langkah bagaimana individu menilai diri mereka sebagai manusia)

8. Family ego (ego dalam keluarga): describes how individuals perceive themselves in relation to significant (menggambarkan bagaimana individu memandang dirinya dalam hubungannya dengan sesama anggota keluarga

9. Social self (sosial): how individuals perceive their value in broader social relationships (bagaimana individu memandang nilai mereka dalam hubungan sosial

10. Self-respect (menghargai dirinya sendiri): how much individuals appreciate themselves and trust themselves (berapa banyak individu menghargai diri mereka sendiri dan percaya pada dirinya sendiri

\section{Metode Penelitian}

Penelitian ini secara sistematik memfokuskan pencarian datanya dari testimoni anak-anak panti asuhan yang sejak bayi telah tinggal di panti asuhan atau yang tidak mengenal orangtuanya sama sekali. Untuk dapat menggali informasi secara mendalam tentang gambaran konsep diri anak asuh di panti sosial penulis menggunakan pendekatan kualitatif dengan teknik wawancara, observasi dan studi kepustakaan, sedangkan jenis penelitian yang dipergunakan pada penelitian ini adalah studi kasus di panti sosial asuhan anak 3 (PSSA 3) milik Dinas Sosial DKI yang berlokasi dimana daerah Cipayung Jakarta Timur dengan mempertimbangkan bahwa panti sosial milik pemerintah daerah merupakan rujukan utama untuk pengasuhan bagi anak terlantar, baik yang berasal dari masyarakat, rumah sakit, kepolisian, dan tidak sedikit yang berasal dari panti sosial anak milik dinas DKI Jakarta, dengan sebagai gambaran ketika awal ditemukan di usia bayi anak-anak tersebut diasuh di panti sosial bayi dan balita, ketika usianya lebih dari 6 tahun mereka dirujuk ke panti sosial anak usia 6-12 tahun, ketika sudah berusia di atas 12 tahun maka mereka dirujuk ke panti sosial ini yaitu PSSA 3. Sehingga dengan beragamnya latar belakang anak asuh menjadi suatu hal yang menarik untuk diteliti, tentunya dengan berpindah-pindahnya panti sosial maka mereka selalu beradaptasi dengan lingkungan panti sosial yang baru, selain itu juga profesi yang bekerja di panti sosial ini lengkap, mulai dari tersedianya pekerja sosial yang bertanggung jawab akan pengasuhan anak, psikolog yang bertugas memberikan penanganan rehabilitasi bagi anak-anak yang mengalami permasalahan psikologis serta memberikan persiapan kepada anak-anak asuh yang akan melanjutkan pendidikannya, selain kedua profesi tersebut juga dibantu oleh para pengasuh dan pendamping yang akan menjadi wali murid bagi anak-anak asuh di panti.

Terdapat 6 informan pada penelitian ini yang terdiri dari 2 orang pekerja sosial, staf dan pengasuh serta 2 orang anak asuh dipanti sosial PSAA 3 yang sedang mengenyam pendidikan SMP 
dan SMA. Pencarian data difokuskan pada 9 instrumen dalam identifikasi gambaran konsep diri, meliputi self critism, identity and self image, behavior, physical self, moral self, personal self, family ego, social self, self respect, yang diadaptasi dari Mlinar and friends melalui jurnalnya (2009:4). Dari keseluruhan transkrip wawancara, observasi dan data studi dokumentasi kemudian dianalisa dengan mempergunakan tiga tahap umum, yaitu reduksi data, pengorganisasian data dan penafsiran data (Sarantakos (1993) dalam Alston dan Bowles (1998)).

\section{Hasil Penelitian}

\section{Gambaran Konsep Diri Anak Panti Asuhan PSAA 3}

Analisa gambaran konsep diri pada anak-anak lintas panti PSAA 3 Ceger didasarkan pada ciri-ciri konsep diri positif maupun negatif yang ada pada diri informan, ditinjau dari aspek pengetahuan, penilaian diri dan pengaharapan, dilihat dari aspek kemampuan untuk bersikap kritis, identitas dirinya, citra diri, prilaku, fisik, moral diri, diri sosial, respek diri, ego individu dalam keluarga.

\section{Dimensi Pengetahuan Informan (T)}

Self critism yang dimiliki oleh informan (T) adalah banyak berbicara mengenai hubungannya dengan lingkungan pertemannya, dimana informan ini sangat menyukai pertemanan yang luas, sehingga dia akan berusaha untuk memperbaiki diri agar bisa diterima oleh teman di panti maupun di sekolah, dan pada akhirnya kesan baik selalu ingin disampaikan oleh informan ini, maka dapat dikatakan bahwa dari sisi self critism yang dikedepankan oleh informan adalah yang positif. Terlihat juga bahwa informan mengetahui tentang kebutuhan dirinya yang merupakan seorang individu yang terbuka terhadap orang lain, hal ini juga ditandai oleh banyaknya teman yang dimiliki oleh informan (T). Bahkan kedewasaan juga terlihat dari persepsi infoman (T) ketika berhadapan dengan permasalahan, dan usia merupakan faktor yang banyak berpengaruh dalam kedewasaan dirinya. Selain itu informan (T) dapat mensyukuri apa yang dimiliki olehnya, sudah merasa cukup puas dengan kondisinya, kalaupun ada yang tidak sesuai keinginannya maka dimana dia tidak merasa terbebani dengan bentuk tubuhnya.

Informan ( $\mathrm{T}$ ) merupakan seseorang yang dalam berprilaku di lingkungan sosialnya bersikap apa adanya dengan mengedepankan prinsip untuk selalu berprilaku baik maka teman pasti akan banyak, selain itu informan (T) merupakan seseorang yang menyukai pertemanan, bahkan dalam berprilaku ia juga mengkaitkan aspek spiritual agama. Penuturan informan (T) terlihat bahwa dia merasa nyaman dengan keberadaannya di panti, karena perhatian yang diterima oleh setiap anak adalah sama. Selain itu informan (T) juga memiliki kemampuan untuk bisa menjadi dirinya sendiri di panti tanpa harus menjadi bayang-bayang anak lainnya.

Informan (T) memiliki sifat untuk menolong sekaligus kemampuan untuk mengukur diri dalam memberikan bantuan, serta memiliki kesadaran untuk menjalankan aturan yang ditetapkan oleh panti, serta merupakan suatu bentuk manifestasi menjadi dewasa yang disadari, namun dia juga menyadari bahwa memiliki sifat keras kepala dan susah untuk diatur.

Informan ( $\mathrm{T})$ menyadari akan kewajibannya sebagai umat Muslim, serta mengetahui kelemahannya akan kemauan untuk beribadah, dan secara tidak langsung dapat disimpulkan bahwa 
tidak mengerjakan sholat adalah suatu kekurangan pada dirinya sendiri yang tidak disukainya.

Informan (T) memiliki sifat untuk menolong sekaligus kemampuan untuk mengukur diri dalam memberikan bantuan, serta memiliki kesadaran untuk menjalankan aturan yang ditetapkan oleh panti, serta merupakan suatu bentuk manifestasi menjadi dewasa yang disadari, namun dia juga menyadari bahwa memiliki sifat keras kepala dan susah untuk diatur.

Informan ( $\mathrm{T}$ ) merupakan orang yang kurang bisa menerima kritikan dari orang lain, terutama terhadap sesuatu yang sudah nyaman pada dirinya dan kurang memiliki motivasi untuk berubah. Namun demikian Informan $(\mathrm{T})$ merupakan remaja yang sabar dan pemaaf, sehingga tidak larut dengan rasa dendam dan marah kepada teman-teman yang mengejeknya, selain itu terlihat juga sisi spiritual pada dirinya, dimana dia lebih banyak berserah diri kepada Allah dibandingkan dengan membalas perbuatan yang tidak menyenangkan dengan kekerasan, baginya status sebagai anak panti bukan sesuatu yang memalukan.

Berdasarkan analisa di atas, dimensi pengetahuan yang ada pada diri informan (T) berupa pengetahuan akan dirinya yang positif bentuk tubuhnya, statusnya sebagai anak panti yang tidak memiliki orang tua, merupakan seseorang yang menyukai pertemanan dan supel dalam pergaulan, suka menolong, merasa dirinya sama sama dengan orang lain walaupun dia anak lintas panti, mampu mensyukuri terhadap apapun yang diperoleh, mudah memaafkan. Pengetahuan negatif akan dirinya meliputi sering meninggalkan sholat, sering kabur dari panti, merokok serta merasa sebagai orang yang agak keras kepala. Masalah-masalah yang dimiliki oleh informan ini dapat dikategorikan disebabkan oleh kondisi perkembangan keremajaannya Calhoun dan Acocella (1990:34). Jika dinilai dari konsep diri yang dimiliki lebih banyak berada pada wilayah konsep diri positif, hal ini bisa dilihat dari pengetahuan akan dirinya serta mampu untuk merasa setara dengan orang lain, sebagaimana yang tertera pada penjelasan tentang ciri-ciri konsep diri negatif yang dikemukakan oleh Rakhmad (2003:106).

\section{Infoman (Y)}

Informan (Y) bisa terbuka kepada orang lain, namun bisa juga menjadi orang yang pemalu jika bertemu dengan orang yang baru ia kenal. Informan (Y) juga menganggap dirinya itu asyik dan berusaha untuk menampilkan hal yang baik di depan orang lain agar dapat diterima oleh orang lain, sehingga hal itu membuatnya ia punya banyak teman. Ketika mendapatkan kritikan informan (Y) akan merespon opini yang dilontarkan orang lain jika itu positif, namun jika sebaliknya akan diabaikan saja olehnya.

Terlihat bahwa informan (Y) merupakan seseorang yang hati-hati dalam bersikap terutama terhadap orang yang baru dikenalnya, hal ini dapat disebabkan bahwa hal yang membahagiakan bagi diri informan (Y) adalah memiliki teman yang banyak, sehingga dia tidak menginginkan kehilangan kesempatan untuk selalu menambah jumlah teman. Namun demikian informan (Y) juga memiliki kecenderungan sebagai seseorang yang peka terhadap kritikan dari orang lain.

Informan juga merupakan tipe orang yang konsisten, dapat dilihat dari sikapnya yang tidak mau meminjamkan barang-barang miliknya kepada orang lain, sekalipun itu teman satu kamarnya, bisa dikatakan bahwa dia merupakan seseorang yang jika sudah memutuskan sesuatu akan berkomitmen sesuai keputusannya tersebut, bisa dikatakan bahwa informan (Y) memiliki kemampuan untuk mempertahankan prinsip atau nilai yang diyakini kebenaran oleh dirinya pribadi. 
Kepuasan akan postur tubuh yang dimiliki ada pada diri informan (Y) karena menurutnya postur tubuhnya sudah pas, walaupun masih mengharapkan agar tubuhnya dapat lebih besar sedikit dari sekarang, selain itu informan (Y) juga menilai bahwa wajahnya tampan disertai dengan tinggi badan yang menurutnya sudah pas. Informan (Y) juga menyadari bahwa saat ini dia bukan lagi anak kecil sehingga hal itu berpengaruh pada kemampuannya untuk memperbaiki perilakunya, keinginannya tersebut didasari akan pemikirannya terhadap akan semakin dewasa dirinya sehingga sudah harus meninggalkan perilaku-perilaku yang tidak baik. Terlihatnya adanya kemampuan dalam diri informan (Y) bahwa dirinya sama dengan orang lain yaitu memiliki kelebihan, terutama pada aspek fisik yang merupakan kebanggan pada diri informan (Y).

Personal self informan $(\mathrm{Y})$ terkait dengan kondisi dirinya masih dengan mudahnya berubah-ubah (labil). Menurutnya, terkadang informan (Y) bersikap biasa saja ataupun cenderung santai, tekadang pula suka bercanda, tetapi jika ia mulai merasa kesepian maka seketika ia pun akan berubah menjadi kesal, terutama jika sedang merasakan kesepian.

Meskipun hubungan informan dengan pengasuh yang lain tidak begitu dekat, namun sebenarnya hubungan informan dengan pengasuh-pengasuh lain baik-baik saja, bahkan informan pun masih mendapat perhatian dari pengasuh lainnya. Hanya saja karakter informan yang tidak terlalu banyak bicara, sehingga hubungan dengan pendampingnya pun hanya sebatas jika informan membutuhkan keperluan terkait dengan sekolahnya. Relasi informan dengan teman-teman di dalam pantinya juga baik, adanya dukungan timbal balik terutama dengan teman-temannya yang memiliki hobi sama dengannya yaitu musik.

Informan (Y) memiliki hobi bermusik khususnya bermain alat musik, dengan adanya fasilitas keterampilan musik yang disediakan oleh panti membuatnya nyaman berada di lingkungan panti, ditandai dengan perasaan bangganya karena lingkungan panti mendukung hobinya, sehingga hobi yang dimilikinya dapat tersalurkan dengan baik. Gambaran konsep diri informan (Y) agak berbeda dengan informan sebelumnya, dimana infroman (Y) memiliki dimensi konsep diri positif dan negatif. Konsep diri positif ini terlihat pada mempertahankan prinsip nilai yang diyakininya, bangga akan bentuk fisiknya, mampu membangun relasi sosial serta mampu memanfaatkan waktu dengan baik, ciri-ciri ini sesuai dengan ciri-ciri konsep diri postif yang dirumuskan oleh rakhmad (2003:106), sementara untuk ciri konsep diri negatif (Erikson dalam Calhoun dan Acocella (1995:72) terlihat pada sensitivitas atau kepekaannya ketika menerima kritikan dari orang lain.

Dimensi Penilaian

Informan $(\mathrm{T})$

Informan ( $\mathrm{T}$ ) merupakan seseorang yang humoris dan terbuka kepada siapa pun sebagaimana yang terdapat dalam wawancara penelitian. Penerimaan akan identitas sebagai anak panti yang melekat pada dirinya membuat informan menjadi mampu bersikap percaya diri serta dapat melihat faktor luar sebagai sistem sumber yang dapat memberikan pertolongan kepada informan, selain itu juga tergambarkan kedewasaan yang dimiliki dengan kemampuannya untuk membuat keputusan yang baik untuk dirinya sendiri, berdasarkan pengalaman yang telah diperolehnya selama ini. Jika ditinjau dari aspek pengetahuan dan penilaian diri sebagaimana yang terdapat pada teori (Partosuwido (1985 : 35) informan (T) merupakan seseorang yang pengetahuan akan dirinya bagus dia tahu tipe kepribadiannya yang terbuka kepada semua orang penilaiannya akan dirinya terlihat positif dimana dia menyukai apa yang ada di dirinya dan tidak malu dengan status yang dimiliki sebagai anak 
panti, dimana pengaharapannya akan dirinya disesuaikan dengan apa yang dimilikinya atau bisa dikatakan gambaran diri yang ada pada dirinya saat ini sesuai dengan harapan yang dia rumuskan, hal ini juga dipengaruhi oleh adanya kemampuan pada diri infoman (T) untuk mensyukuri apa yang dimiliki berdasarkan apa yang dimiliki dibandingkan jika orang lain yang kondisinya lebih tidak menyenangkan darinya..

Informan ( $\mathrm{T}$ ) merupakan seseorang yang dalam berprilaku di lingkungan sosialnya bersikap apa adanya dengan mengedepankan prinsip untuk selalu berprilaku baik kepada orang lain dan merupakan seseorang yang menyukai pertemanan. Kritikan menurutnya bukanlah sesuatu hal yang negatif, bahkan dia menganggap dengan adanya kritikan dapat membuat dirinya menjadi lebih baik, bisa dikatakan bahwa bahwa informan ( $\mathrm{T}$ ) mampu bersikap terbuka dalam menghadapi kritikan yang ditujukan baginya. Mampu untuk berpikir bahwa jika melakukan suatu hal yang baik akan berdampak pada postif bagi dirinya, dan ini dijadikan motivasi bagi dirinya untuk berinteraksi positif dilingkungan sosialnya.

Selain itu informan $(\mathrm{T})$ ini juga mampu untuk mengevaluasi dirinya sendiri mana kekurangan yang menjadi faktor tidak disenangi oleh orang lain, dan kemudian juga berusaha merancang solusi untuk mengatasinya. Kekurangan yang disadarinya berupa kemalasannya untuk mengerjakan sholat walaupun dia mengetahui manfaat sholat yaitu sebagai alat untuk mendapatkan solusi ketika menghadapi masalah, selain itu juga sering manjat tembok panti, kadang ngerokok di panti, namun dengan mampu mengungkapkan sisi kelemahannya berarti kemampuan evaluasi diri dapat dilakukan dengan baik.

Dalam banyak aspek konsep diri seringkali informan $(\mathrm{T})$ mengucapkan kata syukur dengan keadaan yang ada pada dirinya saat ini. Rasa syukur akan apa yang diperoleh terlihat jelas pada diri informan $(\mathrm{T})$, ditandai bahwa dia bisa memilah bahwa yang didapatkannya saat ini jauh lebih baik dari orang lain. Sehingga walaupun ada rasa kekecewaan kepada orang tuanya, namun informan (T) bisa menyadari bahwa ini adalah kehendak dari Tuhan dan hal yang didapatkan saat ini adalah yang terbaik menurut Tuhan, selain itu perasaan untuk bisa menerima keadaaan dirimya merupakan suatu bentuk penyadaran diri bahwa dirinya telah dewasa dan menjadi dewasa adalah bisa bersikap bijaksana, Kedewasaan juga terlihat dari persepsi infoman $(\mathrm{T})$ ketika berhadapan dengan permasalahan, dan usia merupakan faktor yang banyak berpengaruh dalam kedewasaan dirinya

Kemampuannya untuk menganalisa kebutuhan utamanya dengan keinginan yang tidak tercapai membuat informan (T) dapat merespon dengan baik atau dapat dikatakan dirinya dapat beradaptasi terhadap sesuatu yang tidak sesuai dengan harapannya.

Berdasarkan analisa diatas dimensi penilaian diri yang dimiliki oleh informan ( $\mathrm{T}$ ) mengarah kepada konsep diri positif dimana kemampuan dia untuk mengevaluasi dapat dilakukan secara berimbang antara hal positif yang dimilikinya dengan negativf yang menjadi kelemahannya, selain itu indikator konsep diri positif (Hammack dalam Rakhmad 2003:106) terlihat pada diri informan (T), seperti kemampuan untuk yakin akan kemampuan dalam menghadapi masalah seperti yang tercantum di hasil wawancara ketika informan menghadapi masalah maka dia menanggapinya dengan tenang, merasa setara dengan orang lain (Brooks dan Emmert dan dikutip oleh Rakhmad (2003:105), mampu beradaptasi dengan lingkungan dan mampu memperbaiki dirinya karena sanggup mengungkapkan aspek-aspek kepribadian yang tidak disenanginya dan berusaha mengubahnya sebagaimana yang tertera pada salah satu wawancara. 


\section{Informan (Y)}

Agar dapat memiliki banyak teman dan diterima oleh lingkungan sosialnya maka informan (Y) memiliki prinsip harus bisa berbaur dengan lingkungan sosial yang ada, sehingga waktu yang paling disenangi informan $Y$ ketika sedang bersama dengan teman-temannya. Namun demikian informan (Y) menyadari keterbatasan dirinya untuk bermain bersama teman di luar panti, sehingga walaupun menginginkan pertemanan yang lebih luas kondisi keberadaannya di dalam panti menjadikan waktu bermainnya tidak bisa sebebas seperti teman lainnya yang tinggal di luar panti. Selain itu juga Informan (Y) beranggapan bahwa dalam berteman harus bisa memilah mana teman yang baik dan mana yang tidak. Ciri konsep diri positif yang dimiliki oleh informan (Y) mampu menjadikannya seseorang yang memiliki persahabatan yang baik. Selain itu ketika dihadapkan pada permasalahan keterbatasan waktu untuk bermain bersama teman, hal itu disadari oleh informan (Y) dan tidak membuat dirinya menjadi marah, sehingga dalam berinteraksi dengan lingkungan sosialnya dia dapat menikmati tanpa memiliki tekanan pada dirinya. Keberadaan teman bagi informan merupakan suatu yang sangat penting, karena mayoritas waktu mereka dihabiskan bersama teman-teman, sehingga dapat diasumsikan konsep diri yang dimiliki oleh informan $(\mathrm{Y})$ ini lebih banyak dibentuk oleh hubungan pertemanan dibandingkan oleh figure yang lain Calhoun dan Acocella (1990:34).

Lebih lanjut ada kecenderungan pada diri informan (Y) bahwa dia merupakan seseorang yang merasa sama dengan orang lain sehingga dalam memilih teman disesuaikan dengan kriteria yang ditentukan olehnya dan tentunya yang membawa manfaat bagi dirinya, bisa dikatakan bahwa informan (Y) merupakan seseorang yang memiliki kemampuan untuk menolak dirinya dikuasai oleh orang lain karena memiliki kemampuan untuk membuat keputusan khususnya memilih teman yang membawa kebaikan untuknya.

Informan (Y) merupakan orang yang sangat menghargai kemampuan yang dimilikinya, dan juga merupakan orang yang suka dipuji. Dengan mendapatkan pujian dari orang lain ternyata, tidak membuat informan menjadi mudah puas namun hal itu justru memotivasi dirinya untuk terus menjadi baik lagi. Jika hal ini ditinjau dari komponen konsep diri positif Brooks dan Emmert dan dikutip oleh Rakhmad (2003:105) terlihat adanya kejujuran pada pernyataan informan bahwa hal yang membahagiakan dalam dirinya adalah dengan mendapatkan pujian dari orang-orang disekitarnya, namun terlihat juga bahwa dia mampu menggunakan pujian tersebut sebagai dorongan bagi dirinya untuk menjadi pribadi yang lebih baik lagi. Dari temuan lapangan juga diperoleh adanya sikap informan menghargai kemampuan yang dimilikinya serta menerima masukan dari lingkungan sosialnya, bisa dikategorikan sebagai seseorang yang memiliki nilai dan prinsip tertentu yang tangguh untuk dipergunakan sebagai alat untuk evaluasi diri bahkan juga sebagai media untuk mempertahankan pendapatnya jika dia merasa benar dihadapan orang lain.

Selain faktor positif yang dimilikinya ada beberapa kekurangan yang disadari oleh informan dimiliki olehnya, seperti dia merupakan anak remaja yang suka meninggalkan apa yang diperintahkan pengasuh, sehingga bisa dikatakan bahwa kesadaran informan (Y) untuk menjalankan aturan yang ditetapkan di panti masih rendah, khususnya larangan untuk tidak merokok yang sampai dengan saat ini masih sering dilanggar walaupun sudah diperingatkan berkali-kali.

Kebiasaan sering meninggalkan sholat, walaupun mengetahui bahwa sholat itu penting, namun belum dijalankan dengan baik oleh informan (Y). Ada perasaan takut akan dosa jika Ia meninggalkan Sholat, tetapi perasaan takut akan dosa tersebut tidak dijadikannya dorongan untuk ia 
menjadi rajin menjalankan Sholat lima waktu.

Informan (Y) juga menyadari bahwa kesalahan yang telah dilakukan maka akan ada konsekuensi yang diterimanya, misalnya jika meninggalkan sholat maka dosa yang akan diterimanya, selain itu dia juga memahami akan adanya manfaat jika melakukan perbuatan baik yaitu memperoleh pahala.

Informan (Y) merupakan orang yang tidak suka jika ada orang lain yang menjelek-jelekan dirinya, lebih baik menurutnya ditegur secara langsung daripada harus mengomentari dirinya di belakang. Juga merupakan orang yang masih memiliki rasa malas dan terkadang belum bisa melawan rasa malas itu sendiri.

Dari analisa di atas tergambarkan bahwa informan merupakan sesoerang yang jujur untuk menjelaskan berbagai kekurangan yang dimilikinya seperti rasa kecewanya kepada orang yang mengomentarinya tidak langsung kepadanya, sekaligus merupakan seseorang yang belum memiliki pandangan diri yang teratur, hal ini dapat dilihat dari prinsipnya yaitu walaupun dia mengetahui manfaat atau resiko dari sesuatu hal, namun tetap saja dia akan melakukan apa yang disukai.

\section{Dimensi Pengharapan \\ Informan (T)}

Konsep penerimaan akan kondisinya sendiri pada diri informan (T) tergambarkan dalam persepsinya akan harapan terhadap dirinya sendiri serta usaha yang dilakukannya untuk mencapai yang dicita-citakan. Dalam menggapai cita-cita, informan berusaha untuk mewujudkannya dengan melalui usaha untuk berpartisipasi dalam mempergunakan sarana dan prasarana yang dimiliki oleh panti. Kecintaannya pada musik juga memberikan semangat kepadanya untuk belajar dan rajin di sekolah. Selain ingin berkiprah di bidang musik, menjadi orang sukses merupakan suatu hal yang penting bagi diri informan (T) untuk menunjukkan jati dirinya kepada orang lain khususnya orang tua tentang keberhasilannya menggapai cita-cita, dan harapannya tersebut dijadikannya sebagai motivasi dalam usahanya untuk memperoleh kelulusan di ujian nasionalnya di tahun depan.

Dari analisa di atas, terdapat indikator konsep diri positif pada informan (T) sebagaimana yang tertera pada teori (Brooks dan Emmert dan dikutip oleh Rakhmad (2003:105), adanya indikator penerimaan diri, memiliki harapan yang sesuai dengan apa yang dimilikinya, serta dalam memanfaatkan waktu, informan (T) dapat menggunakannya sesuai dengan yang dibutuhkannya khususnya dalam menjalankan usahanya untuk mengejar apa yang dicita-citakan.

\section{Informan (Y)}

Informan (Y) mempunyai keinginan sebagai seorang musisi, dan menurutnya jika sukses itu adalah jika keinginannya tersebut sudah tercapai. Ketika kesuksesan tersebut telah tercapai, akan digunakan sebagai alat untuk mencari orang tuanya serta tidak ketinggalan untuk menyenangkan orang-orang yang pernah mengasuhnya. Keinginan mencari orang tua kandung baru akan dilakukan jika dia merasa dirinya telah mendapatkan kesuksesan, sehingga memperoleh kesusksesan menjadi hal yang penting baginya agar dapat membahagiakan orang tuanya kelak dengan hasil uang keringatnya sendiri.

Adanya keinginan yang kuat untuk dapat bertemu dengan orang tua kandungnya membuat informan Y kerap merasakan sedih dan kecewa jika dirinya menyadari bahwa sampai sekarang 
ia belum dapat menemui orang tuanya. Walaupun ada keinginan untuk mencari keberadaan orang tua kandung, namun keinginan itu baru akan dilakukan jika dia merasa dirinya telah mendapatkan kesuksesan, sehingga memperoleh kesuksesan menjadi hal yang penting baginya. Untuk mencapai cita-citanya dia memiliki rasa tanggung jawab terhadap pendidikannya, terbukti dengan mengatakan "intinya harus fokus sekolah dulu". Informan (Y) juga menganggap bahwa memperbaiki diri untuk menjadi lebih baik itu perlu dan perilaku yang baik itu merupakan pendorong baginya untuk bisa menjadi maju dan menggapai cita-citanya kelak

Jika dilihat dari analisa di atas terlihat adanya komponen konsep diri positif (Brooks dan Emmert dan dikutip oleh Rakhmad (2003:105) yaitu keyakinan pada kemampuannya menghadapi masalah. Masalah disini dapat diartikan dengan rasa kerinduan dan keinginan yang mendalam pada diri informan untuk dapat bertemu dengan kedua orangtuanya. Namun rasa kerinduan tersebut dijadikannya sebagai amunisi untuk memotivasi dirinya meraih kesuksesan dalam hidup agar dapat bertemu dengan kedua orang tuanya. Dorongan untuk bisa mencari dan bertemu dengan orang tua telah membuat suatu komitmen pada diri informan untuk mulai merancang tahapan dalam usaha mencapai kesuksesan, karena informan baru kelas 3 SMP maka rancangannya adalah tamat sekolah dan belajar dengan serius. Dapat disimpulkan bahwa informan (Y) merupakan seorang remaja yang mampu memanfaatkan waktu sesuai dengan kebutuhannya. Kemampuan memanfaatkan waktu merupakan salah satu indikator dalam konsep diri positif. Walaupun terdapat rasa sedih karena tidak mengenal orangtuanya namun terlihat bahwa informan (Y) tidak membuang-buang waktu dalam menyesali kehidupannya dan tidak membenci orang tuanya. Alih-alih membenci, informan (Y) ingin membahagiakan kedua orang tuanya. Dia menyadari bahwa apa yang dialami pada dirinya saat ini merupakan takdir, artinya disini penerimaan diri terhadap apa yang terjadi berlaku pada diri informan.

Selain bercita-cita menjadi orang sukses, informan Y juga melakukan usaha-usaha agar cita-citanya sebagai musisi dapat terwujud. Informan (Y) bukanlah orang yang mudah putus asa. Dengan penekanan pada kata "mencoba, mencoba dan mencoba" menunjukkan bahwa informan memiliki harapan yang tinggi dari terwujudnya cita-citanya tersebut, dan itu semua bukan untuk dikhayalkan melainkan diwujudkan dalam bentuk segenap usaha dan kerja yang mampu untuk dilakukannya.

Berikutnya adalah mengenai rasa kekecewaan dan rasa ingin memiliki sekaligus merasakan apa yang teman-temannya miliki dan rasakan saat ini khususnya ingin memiliki motor, karena informan (Y) beranggapan ia pun sebenarnya sama dengan teman-teman sekolahnya yang lain.

Dapat disimpulkan bahwa informan (Y) kurang mampu untuk menyesuaikan kebutuhannya dengan statusnya sebagai anak panti. Tentunya panti tidak menyediakan fasilitas kendaraan bermotor bagi anak-anak asuhnya. Jadi walaupun informan (Y) merasa bahwa dirinya juga sama dengan temanteman di sekolahnya bisa disimpulkan bahwa dia memiliki pandangan seseorang yang tidak teratur, tidak memiliki perasaan yang stabil dan utuh terhadap dirinya, sebagaimana yang tercantum pada bab teori (Brooks dan Emmert dan dikutip oleh Rakhmad (2003:105), maka konsep diri pada bagian ini adalah negatif karena tidak mengetahui siapa dirinya, apa kekuatan dan kelemahan yang dimilikinya. 


\section{Kesimpulan}

Dari analisa data penelitian disimpulkan bahwa konsep diri yang dimiliki oleh informan (T) dapat dikategorikan ke dalam konsep diri positif, karena dari sekiann banyak aspek yang ditinjau pada dirinya hampir semua indikator konsep diri positif ada pada dirinya seperti mampu bertindak berdasarkan penilaian yang baik, mampu memanfaatkan waktu dengan baik, memiliki keyakinan pada kemampuannya dalam mengatasi persoalan, merasa sama dengan orang lain karena sebagai sesama manusia ia merasa tidak tinggi ataupun rendah, sanggup menerima dirinya sebagai orang yang penting dan bernilai bagi orang lain, cenderung untuk menolak usaha orang lain untuk mendominasnya serta mampu bersikap jujur. Walaupun masih ditemukan kekurangannya pada dirinya namun sedikit banyak dia sudah berusaha untuk memotivasi dirinya untuk menyelesaikan permasalahan dalam dirinya sendiri.

Demikian pula halnya dengan informan Y, tidak jauh berbeda dengan konsep diri yang dimiliki oleh informan ( $\mathrm{T})$, namun yang sedikit membedakannya adalah pada diri informan (Y) ditemukan 1 aspek konsep diri negatif yaitu memiliki pandangan yang tidak teratur akan dirinya serta tidak memiliki perasaan yang stabil dan utuh terhadap dirinya, khususnya dalam hal untuk mengatasi kekurangan dalam dirinya, walaupun dia sudah mengetahui bahwa perbuatannya salah yang mengakibatkan kerugian pada dirinya, namun dia masih belum bisa bergerak secara nyata untuk melakukan perubahan diri, hal ini tentunya juga dipengaruhi oleh faktor umur dimana informan $(\mathrm{T})$ berada di tingkat pendidikan SMA sementara informan (Y) masih di SMP, tentunya pengalaman hidup yang dimiliki oleh informan $(\mathrm{T})$ lebih bervariasi dan banyak dibandingkan dengan informan $(\mathrm{Y})$ dan pada akhirnya mempengaruhi kedewasaan berpikirnya.

Melihat pada temuan lapangan dan analisa kemiripan di antara keduanya terlihat dari minat mereka yang sama yaitu suka berteman dan menyukai bidang musik. Kesukaan mereka akan pertemanan yang luas serta solidaritas dan sikap positif yang selalu ditampilkan kepada orang lain, ini tentunya dipengaruhi oleh kondisi mereka yang tidak pernah mengenal dan memiliki orang tua, sehingga kehilangan kasih sayang dari orang tua mereka dapatkan dari kenyamanan bersama temanteman yang dimiliki, semakin banyak teman maka rasa kekosongan yang dirasakan akan tertutupi oleh rasa bahagia. Karena jika rasa kasih sayang mengandalkan sumbernya dari pengasuh dan pekerja sosial, tentunya tidak akan mampu terpenuhi, dikarenakan jumlah anak asuh yang banyak sementara pengasuh dan pekerja sosialnya yang tentunya belum berimbang dengan jumlah anak asuh di panti PSAA 3 ini.

Sehingga bisa disimpulkan bahwa panti PSAA 3 ini mampu membentuk sistem pertemanan sebagai pengganti sistem pengasuhan alternatif keluarga atau orang tua, hal ini bisa dilihat dari konsep diri yang dimiliki oleh kedua informan lebih banyak berada di konsep diri yang positif.

Sedangkan minat yang sama akan musik, ini juga dipengaruhi oleh lengkapnya fasiltas bermusik yang disediakan oleh panti, beragam alat musik tersedia bahkan pelatih atau guru musik juga didatangkan 1 minggu sekali untuk mengajarkan anak-anak bermain musik. Dengan menyukai musik juga akan berpengaruh terhadap pengelolaan emosi bagi diri remaja, karena adanya rasa senang, bahagia dan nyaman akan membentuk ketenangan pada diri mereka.

Terdapat beberapa masukan yang dihasilkan dari penelitian ini, yaitu berdasarkan temuan lapangan dan analisa, ditemukan potensi yang belum dipergunakan dalam pengasuhan bagi anakanak dipanti sosial, yaitu pertemanan. Kedua anak panti yang dijadikan informan pada penelitian, 
menyebutkan bahwa memiliki banyak teman adalah sesuatu hal yang paling mereka sukai bahkan tidak jarang mereka akan menampilkan hal baik dalam diri mereka agar mendapatkan respon yang baik dari teman-temannya. Pertemanan ini bisa dijadikan sebagai sarana untuk membangun karakter konsep diri positif bagi anak panti, tentunya dengan merancang kegiatan-kegiatan kelompok yang mengarah kepada pembangunan karakter positif pada diri informan, sekaligus juga bisa dijadikan sebagai metode untuk merehabilitasi anak-anak panti yang mengalami permasalahan, misalnya merokok, kabur dari panti, membangkang, melanggar peraturan, dan lain-lain. karena medianya adalah kelompok tentunya lebih mudah bagi mereka untuk saling memberikan motivasi dan edukasi, yang disertai dengan norma yang mereka susun bersama sebagai peraturan yang akan dipatuhi oleh diri mereka sendiri. 


\section{Bibliografi}

Albrecht, S.L, et.al. (1987). Social Psychology 2th. New Jersey : Prentice Hall Inc.

Agustiani, Hendriati. (2006). Psikologi Perkembangan Pendekatan Ekologi Kaitannya dengan Konsep Diri dan Penyesuaian Diri Remaja. Bandung : Refika Aditama.

Alston, Margaret, Bowles dan Wendy. (1998). Research For Social Worker : An introduction to Methods. Melbourne Allen and Unwim.

Burns, R.B. (1979). Self Concept : in Theory Measurement, Development and Behavior. New York : Longman Group Limited.

Calhoun, JF dan Acocella, J.R (1995). Psikologi Tentang Penyesuaian dan Hubungan Kemanusiaan. Semarang : Press Semarang.

Grinder, R.E. (1978). Adolescence. New York : Jhon Willey and Sons Inc.

Rahmat, Jalaludin. (2005). Psikologi Komunikasi. Bandung : Remaja Rosdakarya.

Moleong, Lexy. (2005). Metodologi Penelitian Kualitatif. Bandung : Remaja Rosdakarya.

Murwani, Arita. (2008). Pengantar Konsep Dasar Keperawatan. Yogyakarta : Fitramaya.

Keliat, Budi Anna, dkk. (2005). Proses Keperawatan Kesehatan Jiwa Edisi 2. Jakarta : EGC.

Potter \& Perry. (2005). Buku Ajar Fundamental Keperawatan. Jakarta : EGC.

Singarimbun dan Sofian Effendi (1995). Metode Penelitian Survai. Jakarta LP3ES.

Stuart, Gail \& Sundeen, Sandra. (2005). Buku Ajar Keperawatan Jiwa. Jakarta : EGC.

Suharto, Edi. 2007. Pekerjaan Sosial di Dunia Industri. Bandung : refika Aditama.

Tarwoto dan Wartonah. (2003). Kebutuhan Dasar Manusia dan Proses Keperawatan. Jakarta : Salemba Medika.

Usman, Husaini dan Akbar, Purnomo Setiadi. (2003). Metodologi Penelitian Sosial. Jakarta : Bina Aksara.

Yuliani, Elfi. (2005). Psikologi Perkembangan. Yogyakarta : Teras.

Zastrow, Charles. 1996. Introduction to Social Work and Social Welfare. Pasific Grove : Brooks/ Cole Publishing Company.

\section{Jurnal:}

Mlinar, Suzana, et.al. 200916 (3). Nursing Ethics. Sage Publication. 